\title{
An Elegy of a Patriarch: Boys will be Boys by Sara Suleri
}

\section{Muhammad Nawaz}

\author{
Assistant Professor, English Department, University of Lahore, Chenab Campus, Pakistan \\ $\mathrm{PhD}$ scholar, Imperial University, Lahore, Pakistan
}

\begin{abstract}
Pakistani society is male dominant society and patriarchal values are rife there from her emergence. Sara Suleri's father is a man of words and makes himself clear in firm and clear tone. Sara Suleri has tried to portray this scenario through her memoir Boys will be Boys. Though Sara touches the topics of politics, history and culture of Pakistan but main focus is circumstances in which concept of male gaze seems to be overloaded here. Norms of traditions prevalent in Pakistan always favor male member of society. Male gaze concept is one of the off-shoot of feminist ideology; where patriarchy, dominance and upperhand are norms. Sara Suleri's father is perfect example of patriarchy. He always tried to force his point of view on female family members.
\end{abstract}

Keywords - Patriarchal values, Suppression of Women, Feministic Ideology, Male gaze, dominance.

\section{INTRODUCTION}

Our society assigns different roles to men and women. Men are given dominant role while women are considered subservient to men in different ways. Sometimes these roles are assigned by society but most of times these roles are so-called norms and traditions. It means men in reality decide these roles. These social constructs are major power wielding principals. Sara Suleri's father is a man of words and makes himself clear in firm and clear tone. Boys will be Boys(1995) treat multiple themes (gender and sibling relations, political strife, religion, etc.), but above all these are personal novels, a celebration and remembrance of her English mother as a woman and her father as a man and patriarch. Her father seems to look down upon all other characters through his role and personality. Her mother looks like timid lamb throughout. Boys will be Boys (1995).

Sara Suleri highlights the infeasibility of a comprehensive female recognition in Pakistan by declaring that "There are no women in the third world." (Suleri, 1990: 63). Most feminists agree with the idea that gender inequality is determined by socio-cultural and economic factors rather than biological factors, factors that are not actually acceptable when seem as part of the natural order. Representation of these factors is given in Sara Suleri's Boys will be Boys (1995). In Pakistani society, "women are considered as week" because of their physical structure as well as their role is timid and obedient one because of our customs and traditions" (Suleri, 2006: 656).

Boys will be Boys is a book which shows male dominance in the shape of Sara Suleri's father. The gaze is a complex notion which is related to the power relation found between the observer and the observed object. The theory deals with the complex relationship of watching and being watched, of direct and indirect gazes of the protagonists, but of the spectator as well. The theory of the gaze stems from French post-structuralism, and specifically from Michel Foucault (1980) and Jacques Lacan (1990).

It was especially Lacan (1990) who has brought the psychoanalytical term the gaze in use, with reference to the mirror stage, which consists of a gaze between the subject and reflection through means of the mirror. The term describes the relation between the subject and desire to look but also the awareness that one can be viewed. Therefore, the gaze is often connected with fantasy and desire, especially the subject's desire to control the object it sees. Lacan (1990) talks about cause of desire and object cause of desire in detail. Of course, all this functions in the domain of psychoanalysis, but it can be transported to the history of literature. During the seventies the term has been elaborated to the field of feminism, film studies and social studies in general, as one tends to make a clear distinction between 'the look' and 'the gaze'. While the former is described as the most general term for just seeing, the latter is evidently stated as a special way of looking, determined by gender and by the stance of common reader. The gaze is often associated with masculinity, which confirms the male in dominant position while the female must submit and become an inferior object. It affects the narrative, which becomes affected by the desires and fears of patriarchy.

Laura Mulvey (1920) was one of the most important feminist. She introduced the concept of male gaze 
in her essay named as "Visual Pleasure and Narrative Cinema" (Mulvey, 1990: 63). In the article Mulvey (1990) discussed the conventions of classic literature in connection with certain ideas from the theory of psychoanalysis as she exclaimed that women were objectified in fiction and nonfiction because the heterosexual man was in full control of the fine arts, which is why she accused conventional Hollywood cinema of voyeurism and scopophilia, whereby the male figure gets pleasure from looking at the female body: she is "to-be-looked-at-ness" (Mulvey, 1990: 63).

Basically, Mulvey (1920) wanted to understand, and denounce, the visual focus on women on screen which is exactly what causes her to become weaker sex in particular South Asian countries where female becomes a tool in the hand of patriarchal societal set-up. Sara Suleri's father is a real patriarch. He always looks at the female family members from male point of view. He thinks that women are like animals. They don't have any individuality. They are like just tools in the hands of men. Men should decide their fate. That is what we want to understand and explore in this particular research article and which will be investigated to the fullest. We have to understand why women are considered as weaker. Why men dominate women even while they become educated and have wealth as well as health sometimes both.

\section{NATURE OF THE PROBLEM}

This Study will try to find how male gaze affects the position of women in Pakistani patriarchal society. Sara Suleri's Boys will be Boys is abundantly rich with the examples of male dominance, patriarchy and these memoirs are dominated by the male gaze, typically understood in feminist criticism as the subjugation of the anti-male (the woman) and her recasting as an object for male dominance. By looking at the Sara suleri's Meatless Days, we can easily reach the conclusion that character of "Pip" is dominant one in all ways.

\section{THE FOCUS OF THE PRESENT RESEARCH:}

Division can be made by representation of male gaze in the Sara suleri's writings into one male dominant and patriarchal gaze. Study focuses on Pip in Boys will be Boys. It will discuss the dominance of the traditional patriarchal male gaze. In the chapter on Sara and her father, discussion would be about the traditional patriarchal gaze by the masculine as well as masculine female in the shape of Sara Suleri or her sisters. Finally, the concept of gaze does not narrow the research to some limit. Its broader aspect is to look at the patriarchal and male dominance in the strata of Pakistani society primarily through two memoirs. In the present study feminist perspective of Pakistani society has been shown. Male gaze is a portrayal of the character named as "Pip" and other dominant characters. He is, being, monarch of family and symbol of dominance while Sara suleri's mother is symbol of understanding gaze. She is impressive lady of welsh origin but she plays second fiddle to her husband.

\section{RESEARCH QUESTIONS:}

The questions for the present research are:

(I) How does male gaze affect the position of women in Pakistan particularly shown in Boys will be Boys?

(II) How does Sara interpret male dominance in Boys will be Boys?

(III) What is impact of male gaze in Pakistani patriarchal society?

\section{METHODOLOGY}

The method of qualitative research would be applied to analyze the male patriarchal role in the work of Sara Suleri. The present research will take Boys will be Boys into consideration and try to make text analysis. The present research will analyze it in theoretical framework of male gaze.

\section{DELIMITATION:}

The present research limits itself to the point of view of major character, that is, the father of Sara Suleri in Boys will be Boys. Sara has to cope with the situation that has emerged as a result of the typical patriarchal maledominated norms and traditions prevailing in Pakistan under which women are leading their life.

\section{PEDAGOGICAL IMPLICATION:}

Study definitely shows that women in Pakistan are not given equal status because of typical patriarchal setup of society.

\section{REVIEW OF THE LITERATURE:}

Sara Suleri was just like any girl in Pakistan. She was born in Lahore and her parents were living there at that time. She got bachelor degree from Kinnaird College. She got Masters in English from Punjab University. She got doctorate degree from Indiana University. She recalls memories and interesting incidents of her life in very attractive manner. She also relates the tragic incidents of deaths of her sister and mother. Being daughter of eminent journalist she has made many observations. Her 
observations are elaborative and keen. She uses words at her whim to unfold old memories. Her both memoirs are masterpieces in prose. She uses name of chapters as metaphors. Her memoirs are considered as classics in South Asian Literature. She has published a critical work as well. Its name is The Rhetoric of English India that was published in 1992. It is very complicated work. She tells how English language was used and considered as a tool to portray Sub Continent.

Sara Suleri has written a small and thin memoir which is named as Boys will be Boys. It is a kind of tribute to her father. Her father's name was Zia Ahmed Suleri. He was a close friend of General Zia. Sara used to call her father as "Pip". Her father had a ludicrous personality. He was proved to be a patriotic to the maximum. His habits were singular and preposterous almost all the time. Suleri tells the memories of independence of Pakistan. She talks in detail about her Welsh mother. Sara's mother was beautiful as well as duty bound mother. Sara also talks about her Dadi who was a lady of strong will in her time. She talks about other family members as well. She elaborates in detail about her departure to West.

The writings like Recognition by William. S. Davies (2003), Below the World by Eric Beigbeder (2003), Man of jungle by Lydia Lauren (2003), Reasons and Emotions by John Macarthy (2005), Shadows by Richard Flanagan (2008) serve as the best examples for how dominant male characters still treat female as others. There are other two autobiographical novels: Ruth Ozeki's $M y$ Year of Meats (1998), Tsitsi Dangarembga's Nervous Conditions (1987). The writers of these novelists, both American and postcolonial, portray the female body as site of cultural, racial, and gender inscription. While each text points out the patriarchal and colonial violence against women.

Razi, Rahman, Zenab, Mustaq Memon narrate stories of female usurpation and male chauvinism. All these fiction writings at different times portray male chauvinism at different locations. Ahmed Somro has written a novel named as "Fatma" which narrates the story of three exploited girls. They belong to poor families. Their Parents were rich at some time in the past but the storm of time has made them poor at once. The girls remained miserable and 'other' class through all ups and downs of time. Shah Nawaz is another writer who writes about the role of women in British era. Girls were protected but call girls were common who used to live in Heera Mandee. In this novel she traces idea of male domination. Bundle of characters are presented as men who believe in the dominance of male class. Major and minor characters point towards one direction that women are just serving class. They are not worth any importance. Background of Muslim League as well as Congress has been described in detail in this novel. Novel points out that some questions are still to be answered in context of Partition of Sub-continent. Writer poses question like how conditions of women will change with partition of Sub-continent. Either the improvement in their education system would be emphasized or not? Could they get their rights without any negligence? Are they weaker sex even after partition?

Ahmed serwar in his novel named as "The Blessed Ones" talks about a girl who is being neglected by her family. She could not bear the shackles of society. She runs away from forced marriage but traps herself in the hands of bandits. All of them are ruffians but one of them is different. His name is Asghar. He is powerful as well as modest. Excluding Asghar, all male members in novel try to take advantage of that typical girl. Her name is Safia and she remains pious throughout the novel. It was pure luck that she was not molested or violated because every character wants to snatch her piety and virtue.

\section{CONCEPTUAL/THEORETICAL FRAMEWORK:}

Peter Middleton has theorized that the male gaze "triangulates vision, knowledge, and power". The idea of the male gaze is a definite reality because it seems at once both generic and pervasive. The current theorization of the male gaze is one sided because it limits all gazes into one category and one goal (domination). Male gaze and the psychology of the gaze in general is simple concept; It is proven fact that male gaze is always attached with the notion of masculine dominance. The introduction of the term "the male gaze" can be traced back to Laura Mulvey and her essay "Visual Pleasure and Narrative Cinema" which was published in 1975. In it, Mulvey states that women are obviously the objects, rather than the possessors, of gaze because the control of the camera (and thus the gaze) comes from factors such as the assumption of heterosexual men as the target audience for most genres of literature.

Concept of male gaze was an important part of feminism in the 1970s. It explained that Patriarchy is ideological by nature in South Asian Countries and has an ideological effect in traditional society. Patriarchal society perceives status quo as reality, though that "reality" is put together by exploitation and dominance. The concept of male gaze applies to the whole life of women in this society. Patriarchal set-up of society makes it sure that she 
behaves in good manner. She is observed by brothers, father, and other relatives. She looks herself in mirror of male criteria. Her every act is looked at according to male concepts and ideas. It is believed that biological factors are not reason for this patriarchal dominance. Socio-cultural and economic factors are major cause of it. This gender inequality is caused by the overall male gaze scenario found in society and women are bound to follow it consciously and unconsciously.

Ellie Ragland-Sullivan in her essay seeking the third term: desire, the phallus and materiality of language talks about concept of male gaze in detail. Ellie RaglandSullivan Builds on Lucan's theories of the male gaze as the familiar interpretation that the male strives to find his place as a father-figure, who is supposed to be "an ideal (in the imaginary and symbolic way), but is, in actuality, the source of hindrance."

Ragland- Sullivan argues that a son is placed in "a perturbed position in terms of both ego and desire. $\mathrm{He}$ cannot become the mother. He cannot become the father. $\mathrm{He}$ can only wait from a posture of position of power tacitly promised which is power of patriarchal dominance that comes with gradual process". Much criticism links the male quest for dominance with fears and anxiety, with the male desire functioning as what Ellie Ragland- Sullivan calls "an inherent 'lack-in-being' that motivates humans to seek questions and answers because all subjects are basically incomplete".

Peter Middleton's theory that the male gaze "triangulates vision, knowledge, and power" is true; this "power" is almost always power over women in the creation of an active, dominant gazer and a submissive, objectified subject which is female and weaker person. More exploration into the ideas of vision and knowledge can produce alternative maximum understandings of power, and that these understandings commonly include a binary of dominance and repression.

According to Karen Volland Waters, the ideology of imperialism had "two conflicting facets: superiority of the self over the other and identification of the self with the other."

Waters touches upon the duality of the gaze without understanding that the gaze may not be dual, but may rather be two separate gazes - one of superiority, the other of identification.

Drawing on the works of writers such as Tannen (1990) and other recent prominent writers of language and gender most feminists agree with the idea that gender inequality is determined by socio-cultural and economic factors rather than biological factors, factors that are not acceptable when seen as part of the natural order.

There is a clear distinction between 'the look' and 'the gaze'. As we have explained before, 'the look' is described as the most general term for just seeing, whereas 'the gaze' is obviously stated as a specific way of looking. Furthermore, it is associated with power and determined by gender and by the outlook of patriarchal society, which is why the gaze is often associated with masculinity.

Hence, the gaze confirms the male in dominant position while the female must submit and become an object. During the 1970s feminism has made its association with the psychoanalysis theory of Sigmund Freud and Jacques Lacan, most specific in the theorization of readership, which is associated with Lacan's notion of the gaze. Rosen poses that "from around 1973-74 on, the famous, even infamous answer in Gender became psychoanalytic"; the journal "became an organ that encouraged original English-language work around the association of Freud and Lacan for understanding male gaze."

Lacan sees the gaze and its effects in different way. He says that gaze is not gender or biologically specific thing. Manlove quotes gaze can be divided into three branches: Symbolic gaze, imaginary gaze and real gaze. The idea of gazing was very much important in Lacan,s theories. He describes in detail about male gaze in the mirror active stage. He views the gaze or le regard as the foundation of the development of the Self, which is a process that is started at a very young age due to the confrontation a child has with his mirror image.

The mirror stage symbolizes a rather aggressive tension between the child and its image, as the child sees the image as a whole, complete, perfect, while the child still finds itself lacking a complete and active relationship of the body. The wholeness of the body therefore threatens the child, who experiences fragmented personality.

Role of any woman is established by her gender first and foremost. Role defined by male gaze is understandable in backward area where outward appearances tell the real story.Outer appearances are not always true. But society gives its role to women according to their outer appearance. All persons are manifestation of their outer appearance.

Simome de Beauvoir says that women are considered as "others" and "not male". It is not their fault. This differentiation would remain same because looks always decide. It is logical that literature also shows women in their true color. It is not any fault but it is true to life 
picture. The gaze in fiction or prose may be the outlook of writer but writer also observes society. He does not format norms and traditions. It is the people who assign the roles. So it is not fault of writer or literature to present male gaze in negative way. Gaze can be used as powerful discourse. In 'visual pleasure and narrative cinema' Mulvey represent the culture where woman role is assigned inadvertently. Popular culture has been analyzed by her. She emphasizes that literature and media represent the true color of society. Culture controls images and erotic ways and spectacle.

Women are considered as bearer of meaning not maker of meaning. Mulvey herself accepts this fact. Dominant culture affects women but in marginal way. With inception of feminist theory, circumstances changed for women. They started thinking for themselves. Their path became easy one. Their individual thinking came to be known as feminist thinking. Wisdom and knowledge gave woman enough maturity to think for themselves in the long run. Mulvey suggests that women are never active participators. They are passive and lack imagination to change circumstances into their favor. They are the objects while men are subjects.

\section{ANALYSIS OF "BOYS WILL BE BOYS"}

Sara Suleri reminds many times that she is writing a public history. Death of her sister is a disturbing fact of this history. It is something disturbing in reference to politics in Pakistan. There were doubts about her death when her sister died under mys terious circumstances. It was thought that Ifat was murdered because of her father. $\mathrm{He}$ father was actively participating in politics at that time. He was friend of military dictator of that time. It was suggested that Ifat's death was directly linked with political affinity of her father. She explains that other third world histories are so-called histories. Their facts and figures are intermingled. Facts cannot be removed from fiction in them. They are just mixture of lies.

At the end of few chapters in Boys Will Be Boys she forgets historical background and comes to term with social constraint in the shape of male gaze. She acknowledges that Women are marginalized by male class. She feels a kind of displacement as her homeland is Pakistan. Her mother is Welsh and she is displaced by male dominance of her father. Her mother cannot even speak mother tongue. She looks like a woman from third world with no ideals of western liberty and generosity at hand. Sara herself pointed out this fact that there are no women in third world as they are treated as if they are cows and buffalos with no tongues. She says that women are not even part of active vocabulary. They are just women or no-man and of no importance. She tells about women's exploited identity.

Sara constructs her own identity by shedding light on other family relations. She uses somatic discourse with textual discourse. She says that after her death Ifat becomes just news for her. Throughout both memoirs, Sara changes in many ways. She becomes independent while going to abroad but her contemporaries women in Pakistan are living same cave-like life. They are educated but lens of men consider them as useful and not more than that.

Sara calls her friend Muskatori as piece of land. She uses her as a symbol. Sara uses metaphors and similes to portray personality disorder of all women. They have body but no soul. She shows women in action but in serving position. They are servers as well as slaves. They cook for male members and clean their houses regularly. Their task is to show to men that they are worthwhile for them. Sara uses many names for herself. She calls herself a 'landscape, 'an otherness machine' or a symbol and a state.

Her father measures history by counting the names of male head of governments. Suleri keeps track of history by what goes through her body. She keeps track of history and body. She shows dichotomy that male is direct participant in history while women are artificial characters to fill in the gap. Women keep track of history by remembering what they ate and what is that enters into their body and fills their bodies. When writing about her brother Shahid, she changes her tone and says he was not any male like in Pakistan. He was very much different. He was flexible and reliant.

Mamma (first wife of Pip who was divorced) who was twenty five must have been an argumentative woman but that is not enough reason for divorce. Sara also confesses that this decision would have been tough one for Pip because she knew her father mental set up. It must have been a painful decision for him. The divorce was carried out through public mail and Nuz at nine was told that her mother was her sister.

Boys will be Boys explore the patriarchal society where religion is used to exploit women. For her Pakistan is a place where there is no breathing place for women. Men and male gaze have reduced them to a timid community. In Pakistan women's role is defined by biological factors. When someone has been born as girl child, her role has been decided at the spot. She would now belong to serving class. Male gaze has chosen for her role through the eyes of patriarchal men. So, her role cannot be changed at any 
place. She can gain a little respect by serving men in better way.

She comments in this regard that:

$$
\begin{aligned}
& \text {...we naturally thought of ourselves as } \\
& \text { women, but only in some perfunctory } \\
& \text { physiological way that we happened on } \\
& \text { perchance. Or else it was at maximum a } \\
& \text { practical joke, we thought, hidden } \\
& \text { somewhere among our clothes. But } \\
& \text { formulating that definition is about as } \\
& \text { impossible as attempting to locate the } \\
& \text { illustrious qualities of an Islamic } \\
& \text { landscape. (Suleri 1989, p. 2) }
\end{aligned}
$$

Sara's grandmother observes her religiosity:

In the winter I see her alone, painstakingly dragging her straw mat out to the courtyard at the back of the house and following the rich path of the afternoon sun. With her would go her Quran, a metal basin in which she could wash her hands, and her ponderously heavy spouted water pot, that was made of brass. None of us, according to Dadi, were quite pure enough to carry these particular items. (Suleri 1989, p. 6)

Mr. Suleri who showed no religious bend of mind in early life started praying later. Sara's grandmother who was observant of prayers started leaving prayers at once.

That was a change, when Dadi put herself together again and forgot to put prayer back into its proper pocket, for God could now leave the home and soon would try to join the government. Papa prayed and fasted and went on pilgrimage and read the Quran aloud with most unusual locutions. (Suleri 1989, p. 15)

Sara's mother is displaced and marginalized woman. She remembers her country but never complained about his otherness in other country. She sacrificed all her wishes for her husband's sake. She made conscious effort to become part of Pakistan but she was doubted. People always thought white skin persons as colonizers and could not regard any white lady as loyal to Pakistan or Pakistani nation.
Sara writes:

The touching good faith of her Pakistani passport could not change the fact that even as my mother thought she was arriving, she actually had returned. There was century's worth of mistrust of English women in their gazes when they looked at her who chose to come after the English should have been gone: what did she mean by saying. 'I wish to be part of you?' Perhaps, they feared, she mocked in certain way. (Suleri 1989, p. 163)

Mair Jones is an "other" in the whole family. Her character is contrast to Mr.Suleri who is her husband. She was subservient and obedient all the time. He was always listening to her husband's commands. Sara observed her mother's alienation and adaptation which burdened her. Her mother does not find energy from new state and she could not bring about any change in the thinking of her husband. She resigned to silence while she adjusted to histories and language of Pakistan. Sara's sister had to pay a heavy price for voicing in patriarchal society. She was full of grace, arrogance and self-will. She was always noticed for her beauty. She was bold and rebellious. She disregarded the authority of her father and married without his consent but had nothing in the end. She decided to emphasize in wrong way. She ran away from Kinnaird and married. She was so much brazen that she called a few days later and said that she had married. Pip said congratulations and put down the phone.

She has to bow down to the authority of the husband. It was men who ruled in Pakistan. In order to remain in another family, she has to accept a few rules which she did not like to accept in her father's home. Sara talks about this change at many occasions. She tells that concept of male gaze was fully applied in Pakistan. Women have to suffer or accept the dominance of men. There was no alternative. Her sister once said that women have to face much danger in Pakistan. Men are the true owners of houses but women have the possession of their own bodies. Men in Pakistan have everything to govern and own but women have just body to own.

What energies my sister gave to Pakistan! First she learned how to speak Punjabi and then learned the Jehlum dialect, spoken in the region from which Javed's family belong. She taught herself the 
names and stations of hundred-odd new relatives, guessing how each of them would wish to be addressed. She learned more than I will ever know about the history of the subcontinent and then she turned to polo's ins and outs. (Suleri 1989, p. 141)

Sangeeta further elaborates this point:

It appears that in modern Pakistan, women can be easily and conveniently silenced or easily replaced, being just another wife, mother, or daughter'. (Ray 1993, p. 54)

Pip was even adamant in objection to the rabbits. He used to say that do you know how these things breed. Animals were not allowed in his house without prior permission. Innocent animals could breed in large numbers but that could not come under the control of family patriarch. Then it must be objectionable idea to breed rabbits. He used to say in angry way when I would be sitting and whiling away my time in the sun, writing about great ideas and themes, and those rabbits would be jumping around me-----That is very disgusting idea for Pip.

Sara relates another incident that once again Sara's mother was handling the matters of shifting to other place alone. Was The Pakistan Times so important that Pip could not have taken a day off and have been there to comfort her trembling hands? That was always the matter. Menial jobs were for women. Pip could not do daily chores or participate in them. He was above all these things.

Pip would call his children "mama's pigeons." Being male, he has prerogative to ascribe each and everything in derogative way. One lady from advertisement department complained about molestation by a superior. As the editor of the newspaper Pip fired that superior. In retrospect Sara believes that accused man was innocent and he did not sexually abuse anyone. Sara knew later on that she has a sister hailing from no other place but kasur. That sister was daughter of that lady who complained about sexual harassment. There is another quality of family patriarch. He could marry anybody and at his whim. Nobody could blame him. He is breeder as well as bread earner. Everything is good for him. He can emphasize his point in any way he can. Pip sent Sara with Shahida to buy me a desi wedding gown. Sara told his father that she is already married and she does not need any wedding gown. What was need to buy new dessi wedding gown but all whims and wishes of Pip are important. So Sara bought that
gown.I was in middle school, struggling with mathematics, my mother kindly said, "why dont you ask papa for some help with your homework?" I did, and what help it was. He looked with scorn at my long-division puzzle and then proceeded to say, "Ek Bata Cahr,Do Bata Teran, Tin bata Hazar ,"and this was in rapid Punjabi. I did not speak Punjabi.

Pip would punch people at airports, quite routinely. His family would be there to welcome him home on one of his frequent trips. Sometimes, a lad in the waiting lounge would brush pass Sara or one of her sisters. Forget about Pip, s luggage. He would beat the offender instantly. I am glad you won your games, Pip. It does not make sense that you should lose so many. Sara reminds her father in daydreaming, "Recall the times, Pip, when you would mercilessly tease your son Shahid when he was about four or five by telling him his mother was a monkey, that she had come up to him in Nathia Gali one summer. Pip used to use humiliating language with his own children.

Yet Sara Suleri explains herself. While men have the leisure of autonomy in this society, pure womanhood looks like luxury, ignored in favor of the more pragmatic roles of work and family. Suleri silently chooses to construct her autobiography in terms of the women around her - her own mother, sisters, and friends - in a manner that recognizes the status of women in the third world. Boys Will Be Boys is dominated by personality of Z.A. Sulei who was dictator if real situation is to be described. He himself had wished that if any autobiography would be written by him its name would be Boys Will Be Boys.

\section{CONCLUSION}

Boys will be Boys is a kind of elegy for her father and it revolves around her father. His father was Z.A. Suleri was nicknamed as Pip. This book has no definite structure. Reminiscences just come and go without any sequence. Sara addresses her father in a naughty manner. She sometimes admires him and sometimes feels perturbed at his behavior. Throughout the book the personality of her renowned father is portrayed in strange manner. It was said that he had a 'lion's head' and 'memorable gaze'. Throughout both books comments made by pip are important. His conversations and quirks are considered as important. Sara Suleri sees patriarchal social systems as the fundamental cause of women's oppression and she fights for the elimination of male dominance particularly in the cultural sphere, and 'placing women and girls' experiences at the center of any exploration and analysis through her both memoirs named as Boys will be Boys. 
Pakistan is one of the worst countries where patriarchal set up has treated women in heinous way. Maltreatment is worse term in Pakistan scenario though it is true that women are being maltreated. Only in Congo and War torn Afghanistan condition is worse than Pakistan. Eighty percent of women are suffering from domestic violence. One in the three women has to face the stigma of rape if they have no relative for survival. Our country is eighty second of ninety two on gender index. This country is on the 152 number out of 156 on the gender Empowerment measure. Negative sex ration of Pakistan is 100 women out of 108.5 men. We can easily conclude that Sara suleri through Boys will be Boys has given us the male gaze view in Pakistani Patriarchal society. Women are easy victim there so their situation needs to be changed.

\section{REFERENCES}

[1] Chaudhuri, Shohini. Feminist Film Theorists: Laura Mulvey, Kaja Silverman, Teresa de Lauretis, Barbara Creed. New York: Routledge, 2006

[2] Doane, Mary Ann. Femmes Fatales: feminism film theory, psychoanalys is. New York: Routledge, 1991

[3] Gallop, Jane. "The Monster in the Mirror: The Feminist Critic's Psychoanalysis." Feminism and Psychoanalysis. Ed. Richard Feldstein and Judith Roof. Ithaca, NY: Cornell University Press, 1989.

[4] Girard, Rene. Deceit, Desire and the Novel: Self and Other in Literary Structure.

[5] Grosz, Elizabeth. Jacques Lacan: A Feminist Introduction. London: Routledge, 1990 Hall, D. (2004) Subjectivity, New York Routledge.

[6] Hein Carolina. Laura Mulvey, Visual Pleasure and Narrative Cinema - Seminar Paper. 2006

[7] Lacan, Jacques. Feminine Sexuality. London: W W Norton \& Co Inc, January 1983.

[8] Lacan, Jacques. The Ego in Freud's Theory and in the Technique of Psychoanalysis. 1954-1955. London: W W Norton \& Co Inc, June 1988.

[9] Lacan, Jacques. The Language of The Self: The Function of Language in Psychoanalysis. Baltimore, Maryland: Johns Hpkins University Press, 1997.

[10] McGrowan, Todd. 'Looking for the Gaze: Lacanian Film Theory and Its Vicissitudes.' Cinema Journal 42, 3 (2003): 27-47

[11] Merck, Mandy, 'Mulvey's Manifesto.' Camera Obscura 22, 66 (2007): 1-23 (Academic Search Elite).

[12] Middleton, Peter. The Inward Gaze: Masculinity and Subjectivity in Modern Culture. London: Routledge, Chapman, and Hall, Inc. 1992.
[13] Morris on, Karl F. The Male Gaze and Other Reasons for the Hypothetical End of Christian Art in the West. Ontario, Canada: Pontifical Institute of Mediaeval Studies, 2005.

[14] Mulvey, Laura, "Visual Pleasure and Narrative Cinema." Screen 16.3 (Autumn 1975): 6-18

[15] Mulvey, Laura. 'Looking at the Past from the Present: Rethinking Feminist Film Theory of the 1970s.' Signs 30, 1 (2004): 1286-1292

[16] Mulvey, Laura. Visual and Other Pleasures. Indiana: Indiana University Press, 1989.

[17] Penley, Constance (ed.). Feminism and Film Theory. NewYork: Routledge, 1988

[18] Regland-Sullivan, Ellie. "Seeking the Third Term: Desire, the Phallus, and the Materiality of Language." Feminism and Psychoanalysis Ed. Richard Feldstein and Judith Roof. Ithaca, NY: Cornell University Press, 1989.

[19] Samuels Robert. Hitchcock's Bi-Textuality: Lacan, Feminisms, and Queer Theory. Albany: State University of New York Press, 1998

[20] Snow, Edward. "Theorizing the Male Gaze: Some Problems. "Representations No. 25 (Winter, 19890): 30-41

[21] Stoddart, Jackie. Star gazing: Hollywood cinema and female spectatorship. London/New York: Routledge, 1994

[22] Technologies of Gender: Essays on Theory, Film and Fiction. Bloomington: Indiana University Press, 1987

[23] The Real Gaze: Film Theory after Lacan. Albany: State University of New York Press, 2007

[24] 'Visual and Other Pleasure.' Hampshire/New York: Palgrave MacMillan, 1989

[25] 'Visual Pleasure and Narrative Cinema.' Screen 16, 3 (1975): 1-12. Death 24x a Second: Stillness and the Moving Image. London: Reaktion Books Ltd, 2006. 